\title{
Dişeti Çekilmesi: Yetişkin Bir Alt Popülasyonda İnsidans ve İlişkili Faktörler
}

\section{Gingival Recession: Incidence and Associated Factors in an Adult Subpopulation}

\author{
Nazlı Zeynep ALPASLAN YAYLI@1*, Elif TÖRE SARİ1
}

Atıf Yapmak İçin: Alpaslan Yaylı NZ., Sari ET. Dişeti çekilmesi: Yetişkin bir alt popülasyonda insidans ve ilişkili faktörler. Van Sag Bil Derg 2021, $14,(2)$ 217-228.

https://doi.org/10.52976/vansagl ik.942756.

Geliş Tarihi:25/05/2021

Kabul Tarihi:14/07/2021

Basılama Tarihi: 30/08/2021
1 Van Yüzüncü Yıl Üniversitesi, Diş Hekimliği Fakültesi, PeriodontolojiA.D. Van, TÜRKIYYE.

* Sorumlu yazar: Nazlı Zeynep ALPASLAN YAYLI; E-mail: nzeynep 5@hotmail.com

\section{ÖZET}

Amaç: Bu çalışmanın amacı yetişkin bir alt popülasyonda diş eti çekilmesi insidansı ile periodontal ve epidemiyolojik değişkenleri içeren olası risk faktörleri arasındaki ilişkiyi araştırmaktır.

Materyal ve Metot:Bu çalışma 18-53 yaş arasında bulunan 140 gönüllü hasta üzerinde yürütülmüştür. Tüm katılımcıların demografik bilgileri, oral hijyen alışkanlıkları, diş hekimi ziyaret sıklı̆̆ı, anormal alışkanlık varlığı, sigara kullanımı ve sistemik durumu kayıt altına alınmıştır. Klinik muayenede diş eti çekilmesi tespit edilen 211 alanda, ark dışı diş varlığı, dişlerde malpozisyon, aşınma, fırça izi, mobilite, dentin hipersensitivitesi, oklüzal travma, primer kontakt varlı̆̆ı, anormal restorasyon kenarları, anormal frenulum varlığı, yapışık dişeti genişliği ve periodontal sağlık durumunu içeren çeşitli değişkenler incelenmiştir.

Bulgular: Katılımcıların \%89,3' ü sistemik olarak sağlıklı olup, \%77,9' u sigara kullanmamaktadır. \%31,4 oranında katılımcı yılda 2 kez diş hekimi ziyareti yapmaktadır. Bireylerin $\% 47,9^{\prime}$ u günde iki kez diş fırçaladığını belirtmiş, ancak tüm katılımcıların yalnızca \%16,4' ünün doğru teknikle fırçaladığı gözlenmiştir. Dişeti çekilmesi riski bulunan hastalar toplam bireylerin $\% 52,1^{\prime}$ ini oluşturmaktadır. Bu bireylerin ise $\% 58,9^{\prime}$ unda dentin hipersensitivitesi, \%35,6' sında frenulum faktörü ve \%32,9' unda yetersiz yapışık dişeti tespit edilmiştir. Dişeti çekilmesi yaşla birlikte anlamlı şekilde artmıştır $(p<0,05)$. Periodontitis teşhis edilen bireylerdeki dişeti çekilmesi oranı ise gingivitis teşhis edilenlerden anlamlı şekilde daha fazladır $(\mathrm{p}<0,05)$.

Sonuç: Bu çalışmanın sınırları dahilinde, periodontal sağlık durumu, fırçalama tekniği, yetersiz yapışık dişeti ve dentin hipersensitivitesi dişeti çekilmesi ile ilişkili faktörler olarak öne çıkmaktadır.

Anahtar Kelimeler: Diş eti çekilmesi, Etiyoloji, İnsidans.

\begin{abstract}
Objective: The aim of this study is investigating the relationship between the incidence of gingival recession and possible risk factors including periodontal and epidemiological variables in an adult sub-population. Material and Method: 140 volunteer patients between the ages of 18-53 were conducted to the study. Demographic information, oral hygiene habits, frequency of dental visits, bad habits, smoking and systemic conditions of all participants were recorded. In clinical examination, 211 gingival recession detected are as were inspected and various variables including the presence of non-archteeth, malposition, abrasion, brush marks, mobility, dentin hypersensitivity, occlusal trauma, presence of primary contact, poorly contoured dental restorations, presence of abnormal frenum, attached gingival width and periodontal health status were examined.

Results: $89.3 \%$ of the participants were systemically healthy and $77.9 \%$ did not smoke. $31.4 \%$ of the participants visited the dentist twice a year. $47.9 \%$ of the individuals stated that they brushed their teeth twice a day, but only $16.4 \%$ of all participants were observed to brush with the correct technique. Patients with gingival recession constitute $52.1 \%$ of the total individuals. $58.9 \%$ of these individuals had dentin hypersensitivity, $35.6 \%$ had frenum factor and $32.9 \%$ had inadequate attached gingiva. The risk of gingival recession has increased significantly with age $(\mathrm{p}<0.05)$. The rate of gingival recession in individuals diagnosed with periodontitis is significantly higher than those with gingivitis $(\mathrm{p}<0.05)$.

Conclusion: Within the limitations of this study, periodontal health status, tooth brushing technique, inadequate attached gingiva and dentin hypersensitivity stand out as factors associated with gingival recession.
\end{abstract}

Keywords: Gingivalrecession, Etiology, Incidence.

\section{GİRİ̧̧}

Dişeti çekilmesi, dişeti kenarının mine-sement birleşiminin apikaline doğru yer değiştirmesi sonucu kök yüzeyinin açı̆̆a çıkması olarak tanımlanır. Birçok etiyolojik faktöre bağlı olarak gelişebilen dişeti çekilmeleri, bireylerde fonksiyonel ve estetik rahatsızlılara neden olabilmektedir (Shkreta ve ark., 2018). Kök yüzeyinin ağız ortamına maruz kalması ve dental plak birikimindeki artış nedeniyle tabloya dentin hipersensitivitesi, kök çürükleri, abrazyon, servikal aşınma ve erozyon da eşlik edebilmektedir (Tugnait ve Clerehugh, 2001; Addy, 
2005). Dişeti çekilmeleri, periodontal hastalık varlığında veya yokluğunda, ağız hijyeni iyi olanlarda veya kötü olanlarda ortaya çıkabilmektedir (Kassab ve Cohen, 2003; Seong ve ark., 2018). Lokalize veya generalize olarak karşılaşılabilmekte ve bir veya daha fazla diş yüzeyini etkileyebilmektedir. En sık bukkal bölgenin etkilendiği gösterilmiştir (Kassab ve Cohen, 2003). Yapılan bazı çalışmalarda, bireylerin \% 64' ünün en az bir veya daha fazla dişinde açık kök yüzeyi bulunduğu (Chrysanthakopoulos, 2014), erkeklerde ve yaşlilarda ise dişeti çekilmesi prevalansının daha yüksek olduğu gözlenmiştir (Susin ve ark., 2004).

Gelişme mekanizması tam olarak anlaşılamayan dişeti çekilmelerinin etiyolojisi de çok faktörlü ve karmaşıktır. Etiyoloji üzerine yapılan çalışmalarda kemik dehisensleri (Bernimoulin ve Curilovié, 1977), yetersiz keratinize dişeti genişliği, ince dişeti biyotipi, diş malpozisyonu (Zucchelli ve ark., 2006), anormal frenulum varlığ (Sangnes ve Gjermo, 1976) gibi predispozan anatomik risk faktörlerinin yanı sıra; dental plağa bağlı iltihaplanma, uygun olmayan diş fırçalama alışkanlıkları (Vehkalahti, 1989; Tugnait ve Clerehugh, 2001), sigara kullanımı (Banihashemrad ve ark., 2008), travmatikoklüzyon ve uygun olmayan restoratif, protetik, ortodontik ve periodontal prosedürlerle ilişkili iyatrojenik faktörler (Tugnait ve Clerehugh, 2001; Chrysanthakopoulos, 2013) dişeti çekilmesi ile ilişkili faktörler olarak öne çıkmaktadır.

Dişeti çekilmesi görülen alanlarda eşlik edebilen estetik ve fonksiyonel sorunlar ve dentin hipersensitivitesi gibi faktörler yaşam kalitesini olumsuz yönde etkilemektedir (Addy, 2005; Bekes ve Hirsch, 2013; Seong ve ark., 2018). Yüksek yaygınlığı göz önüne alındığında, dişeti çekilmesi ile dişeti iltihabı, periodontals ondlama derinliği, dentin hipersensitivitesi, hijyen uygulamaları vb. faktörler arasındaki ilişkinin daha iyi anlaşılma-sı gerekliliği doğmaktadır. Dişeti çekilmesi ve ilişkili faktörlerin iyi bir şekilde anlaşılması, dişeti çekilmesi vakalarının başarılı bir şekilde ve öngörülebilir uzun vadeli sonuçlarla yönetilebilmesini sağlayacaktır. Dişeti çekilmesi için belirlenen risk faktörlerinin nedensel etkisine ilişkin tutarlı kanıtların bulunmaması, bu koşulların sağlık üzerindeki etkisiyle birlikte, hastalık ve nedenleri hakkında daha fazla araştırma yapılması ihtiyacını ortaya koymaktadır. Tüm bunlara ek olarak dişeti çekilmesinin Türk popülasyonunda yaygınlığ rin de sinırlı olduğu gözlenmektedir.

$\mathrm{Bu}$ bilgiler ışı̆̆ında, mevcut kesitsel çalışmanın amacı Doğu Anadolu Bölgesi'nde yaşayan yetişkin bir popülasyonda dişeti çekilmesi insidansı ile periodontal ve epidemiyolojik değişkenleri içeren olası risk faktörleri arasındaki ilişkiyi araştırmaktır.

\section{MATERYAL ve METOT}

\section{Araştırmanın tipi}

$\mathrm{Bu}$ araştırma gözlemsel, kesitsel ve epidemiyolojik bir çalışmadır.

\section{Araştırmanın evreni ve örneklemi}

Araştırma Van Yüzüncü Yıl Üniversitesi Diş Hekimliği Fakültesi Periodontoloji Kliniği'ne Nisan 2020 ve Mart 2021 tarihleri arasında rutin dișeti tedavisi için başvuran ve yaşları 18-53 (ort. 31,9 \pm 9,2) arasında değişen 63'ü erkek 77' si kadın toplam 140 birey üzerinde yürütülmüştür. Veriler, kendi kendine uygulanan bir anket ve bir klinik muayene yoluyla toplanmıştır. Anket epidemiyolojik değişkenler, sigara içme durumu, sistemik hastalık olup olmadığı, eğitim seviyesi, diş hekimi ziyaret sıklığı, ağız hijyeni uygulamaları vb. hakkında bilgi edinmek için kullanılmıştır. Klinik muayenede ise mevcut ağı içi durumun detaylı periodontal değerlendirmesi yapılmıştır. Katılım kriterleri, çalışma için gönüllü olmak, ankette bulunan soruları cevaplayabilecek bilişsel yeteneği olmak, hijyen uygulamaları için bedensel veya zihinsel bir engeli bulunmamak ve 18-65 yaş aralığında olmak şeklinde sıralanmıştır. Son altı ay içerisinde periodontal tedavi öyküsü bulunanlar, oklüzal düzeltme yapılan bireyler ve ortodontik tedavi öyküsü olanlar ise çalışmaya dahil edilmemiştir. 


\section{Veri toplama araçları}

\section{Anket}

Klinik muayene öncesi tüm katılımcılardan kişisel bir anket doldurmaları istenmiştir. Anket cinsiyet ve yaşı içeren demografik bilgileri, eğitim düzeyini, meslek bilgisini, sistemik bir hastalık olup olmad1ğını, sigara kullanım durumunu, diş hekimi ziyaret sık-lığını, diş fırçalama sıklığı ve diş ipi kullanımını içeren ağız hijyeni uygulamalarını, anormal alışkanlık olup olmadığı vb. değişkenleri değerlendirmek için uygulanmıştır.

\section{Klinik muayene}

Kişisel bilgi formunun doldurulmasını takiben, periodontoloji kliniğinde rutin olarak kullanılmakta olan Williams tipi (PQW7, Hu-Friedy, Chicago) periodontalsond ile tüm katılımcıların periodontal muayeneleri yapılmıştır. Tüm klinik muayeneler tek bir klinisyen tarafından 3. molar dişler dışında tüm dişleri içerecek şekilde gerçekleştirilmiştir.

Hatalı diş fırçalama yapılıp yapılmadı ğı hem hastanın sözlü anlatımı hem de diş yüzeyinde servikal aşınma olup olmadı ğ1 incelenerek tespit edilmiştir. Açığa çıkan diş yüzeyinde plak olmaması ve parlatılmış olmasına dikkat edilmiştir.

Sondlamada kanama (Ainamo ve Bay, 1975), plak varlığı (Sılness ve Loe, 1964), dişeti çekilmesi varlığı (mine-sement sınırından dişeti marjinine kadar olan mesafe) ve periodontal teşhis (gingivitis-periodontitis) (Caton ve ark., 2018) değişkenlerini içeren ön bir klinik inceleme yapılmıştır. İnceleme sonrasında, dişeti çekilmesi bulunan alanlarda etiyolojik nedenlerin ve ilişkili faktörlerin araştırılması açısından daha detaylı bir muayeneye geçilmiştir. Dişeti çekilmesi olan alanlarda, ark dişı diş varlığ1 ve dişlerde malpozisyon olup olmadığ 1 (oklüzal düzleme göre dişlerin arkın normal kavsine göre, labiale veya linguale konumlanıp konumlanmadığı), aşınma varlığı, diş fırçası izi, mobilite (Hanamura ve ark., 1987), oklüzal travma (tekrarlayan alışılmış sentrik kapatma sırasında dişlerin yüzeylerine işaret parmağı yerleştirilerek fremitus varlığ1/yokluğu tespit edilmiştir), primer kontakt, anormal restorasyon kenarları, frenulum faktörü (Mirko ve ark., 1974), yeterli yapışık dişeti varlığı ve dentin hipersensitivitesi (hekim tarafından 3 saniye uygulanan hava spreyi yardimiyla provakasyonla ağrı tespiti) olup olmadığ1 incelenmiştir. Yapışık dişeti genişliğini doğrulamak için tansiyon testi yapılmıştır (Kisch ve ark., 1986). Deneyimli bir teknisyen, yalnızca şüpheli durumlarda ilgili dişlerin standart periapikal radyografilerini almıştır.

\section{Verilerin analizi}

$\mathrm{Bu}$ kesitsel araştırmanın verileri IBM® Statistical Package for the Social Sciences (SPSS) V23 ile analiz edilmiştir. Dişeti çekilmesine etki eden risk faktörlerinin incelenmesinde ikili lojistik regresyon analizi kullanılmış ve çoklu modelde bağımsız risk faktörleri modele Backward: Wald metodu ile eklenmiştir. İkili gruplara göre normal dağılan nicel verilerin karşılaştırılmasında Bağımsız iki örnek $t$ testi ve normal dağılmayan verilerin karşılaştırılmasında Mann-Whitney U testi kullanılmıştır. Analiz sonuçları kategorik veriler için frekans ve yüzde olarak, nicel veriler için ise ortalama \pm standart sapma ve ortanca (minimum-maksimum) şeklinde sunulmuştur. Önem düzeyi $p<0,05$ olarak alınmıştır.

\section{Etik izin}

Çalışma için Van Yüzüncü Yıl Üniversitesi Klinik Araştırmalar Etik Kurulu'ndan onay alınmış, ve Helsinki İlkeler Deklarasyonuna uyularak gerçekleştirilmiştir (04.03.2020/03). Araştırmaya katılan tüm bireyler çalışma hakkında detaylı bir şekilde bilgilendirilmiş ve her birine aydınlatılmış onam formu imzalatılmıştır.

\section{BULGULAR}

Çalışmaya katılan bireylerin $77^{\prime}$ si kadın (\%55), 63' ü erkek (\%45) olup, yaşları 18-53 (ort. 31,9 $\pm 9,2$ ) arasında değişmektedir. \%38,6 oranında katılımcı üniversite mezunudur. $\% 89,3$ oranında katılımc1 sistemik olarak sağlıklı bireylerden oluşmakta ve $\% 77,9$ oranında katılımc sigara kullanmamaktadır. Bireylerin \%31,4' ünün yılda iki kez diş hekimini ziyaret ettiği, \%47,9' unun günde 2 kez diş furçaladığ1 ancak yalnızca \%16,4' ünün doğru teknik 
kullandığı ve yalnızca \%6,4' ünün diş ipi kullandığı mamaktadır. Bireylere ait kategorik değişkenlerin tespit edilmiştir. \%95 oranında katılımcının anormal frekans dağılımı Tablo 1' de gösterilmiştir. alışkanlıkları (bruksizm, tırnak yeme vb.) bulun-

Tablo 1. Katılımcılara ait kategorik değişkenlerin frekans dağılımı.

\begin{tabular}{|c|c|c|}
\hline & Frekans (n) & Yüzde (\%) \\
\hline \multicolumn{3}{|l|}{ Cinsiyet } \\
\hline Kadın & 77 & 55,0 \\
\hline Erkek & 63 & 45,0 \\
\hline \multicolumn{3}{|l|}{ Eğitim düzeyi } \\
\hline Üniversite & 54 & 38,6 \\
\hline Ortaöğretim & 50 & 35,7 \\
\hline İlköğretim & 33 & 23,6 \\
\hline Eğitim almamış & 3 & 2,1 \\
\hline \multicolumn{3}{|l|}{ Mesleği } \\
\hline Çalışmıyor & 43 & 30,7 \\
\hline Öğrenci & 38 & 27,1 \\
\hline Serbest & 24 & 17,1 \\
\hline Öğretmen & 11 & 7,9 \\
\hline Esnaf & 5 & 3,6 \\
\hline Memur & 5 & 3,6 \\
\hline Doktor & 3 & 2,1 \\
\hline Mühendis & 2 & 1,4 \\
\hline Sağlık personeli & 2 & 1,4 \\
\hline Asker & 1 & 0,7 \\
\hline Çiftçi & 1 & 0,7 \\
\hline Din görevlisi & 1 & 0,7 \\
\hline Eczac1 & 1 & 0,7 \\
\hline Emekli & 1 & 0,7 \\
\hline Hastane personeli & 1 & 0,7 \\
\hline İşletme & 1 & 0,7 \\
\hline \multicolumn{3}{|l|}{ Sistemik durumu } \\
\hline Sistemik hastalık yok & 125 & 89,3 \\
\hline Sistemik hastalık var & 15 & 10,7 \\
\hline \multicolumn{3}{|l|}{ Sigara kullanımı } \\
\hline Kullanmiyor & 109 & 77,9 \\
\hline Kullaniyor & 31 & 22,1 \\
\hline \multicolumn{3}{|l|}{ Diş hekimi ziyaret sıklığı } \\
\hline Yilda bir & 50 & 35,7 \\
\hline 6 ayda bir & 44 & 31,4 \\
\hline Yilda 1'den az & 42 & 30,0 \\
\hline Hiç Gitmeyen (ilk) & 4 & 2,9 \\
\hline
\end{tabular}


Tablo 1. Devamı

\begin{tabular}{|c|c|c|}
\hline & Frekans (n) & Yüzde (\%) \\
\hline \multicolumn{3}{|l|}{ Diş fırçalama sıklı̆̆ı } \\
\hline Günde 2 kez & 67 & 47,9 \\
\hline Günde 1 kez & 47 & 33,6 \\
\hline Haftada birkaç kez & 19 & 13,6 \\
\hline Hiç furçalamayan & 5 & 3,6 \\
\hline Haftada 1 kez & 2 & 1,4 \\
\hline \multicolumn{3}{|l|}{ Diş ipi kullanımı } \\
\hline Kullanmiyor & 131 & 93,6 \\
\hline Kullaniyor & 9 & 6,4 \\
\hline \multicolumn{3}{|l|}{ Sağ-sol el kullanımı } \\
\hline Sağ elini kullanma & 133 & 95,0 \\
\hline Sol elini kullanma & 7 & 5,0 \\
\hline \multicolumn{3}{|l|}{ Anormal alışkanlıklar } \\
\hline Yok & 133 & 95,0 \\
\hline Var & 7 & 5,0 \\
\hline \multicolumn{3}{|l|}{ Firçalama tekniği } \\
\hline Yanlış teknikle furçalayan & 117 & 83,6 \\
\hline Doğru teknikle fırçalayan & 23 & 16,4 \\
\hline Yaş & $31,9 \pm 9,2$ & $31,0(18,0-53,0)$ \\
\hline
\end{tabular}

Çalışmaya dahil edilen bireylerin $\% 52,1^{\prime}$ inde $(n=73)$ dişeti çekilmesi (toplam 211 dişte), \%76,4' ünde $(\mathrm{n}=107)$ sondlamada kanama, $\% 85,7^{\prime}$ sinde $(\mathrm{n}=120)$ plak varlığ1 tespit edilmiştir. \%75,7 ( $\mathrm{n}=106)$ oranında katılımcının gingivitis olduğu gözlenmiştir. Dişeti çekilmesi olan bireylerin $\% 11^{\prime}$ inde $(n=8)$ ark dışı diş mevcudiyeti, \%5,5' inde $(n=4)$ dişlerde malpozisyon, \%16, $4^{\prime}$ ünde $(n=12)$ dişlerde aşınma, $\% 20,5^{\prime}$ inde $(n=15)$ dişlerde mobilite, \%58, $9^{\prime}$ unda $(n=43)$ dentin hipersensitivitesi, \%11' inde $(n=8)$ oklüzal travma, \%35,6'sinda $(n=26)$ frenulum faktörü ve $\% 67,1^{\prime}$ inde $(n=49)$ yetersiz yapışık dişeti genişliği tespit edilmiştir. Dişeti çekilmesi ile ilişkili faktörlere ait kategorik değişkenlerin frekans dağ1lımı Tablo 2' de gösterilmiştir.
Dişeti çekilmesine etki eden faktörler ikili lojistik regresyon analizi ile incelenmiş ve Tablo $3^{\prime}$ te gösterilmiştir. Dişeti çekilmesine etki eden faktörler tek değişkenli ve çoklu lojistik regresyon analizi ile incelenmiştir. Yaş artıkça dişeti çekilmesi 1,063 kat artmaktadır $(p=0,001)$. Tek değişkenli modele göre periodontitis teşhisi olanların dişeti çekilmesi riski, gingivitis teşhisi olanlara göre 3,903 kat $(p=0,001)$, çoklu lojistik regresyon analizine göre ise 4,368 kat daha fazladır ( $p=0,001)$. Doğru teknikle diş fırçalayanların dişeti çekilmesi riski, doğru teknikle fırçalama yapmayanlara göre 3,432 kat daha azdır $(p=0,011)$. Çalışma sonuçları, sigara kullanımı ile dişeti çekilmesi arasında anlamlı bir ilişki göstermemiştir ( $p>0,05)$. 
Tablo 2.Dişeti çekilmesi ile ilişkili faktörlere ait kategorik değişkenlerin frekans dağılımı

\begin{tabular}{ccr}
\hline \hline & Frekans (n) & Yüzde \\
\hline \hline Dişeti çekilmesi & & \\
Yok & 67 & 47,9 \\
Var & 73 & 52,1
\end{tabular}

Ark dışı dişler

$$
\text { Yok }
$$

Var

Malpozisyon

$$
\text { Yok }
$$$$
\text { Var }
$$

Aşınma

$$
\begin{aligned}
& \text { Yok } \\
& \text { Var }
\end{aligned}
$$

Fırça izi

$$
\text { Yok }
$$$$
\text { Var }
$$

Mobilite

$$
\begin{aligned}
& \text { Yok } \\
& \text { Var }
\end{aligned}
$$

Dentinhipersensitivitesi

$$
\text { Yok }
$$$$
\text { Var }
$$

Oklüzal travma

$$
\text { Yok }
$$$$
\text { Var }
$$

Primerkontakt varlığı

$$
\text { Yok }
$$

Var

Anormal restorasyon kenarları

$$
\begin{aligned}
& \text { Yok } \\
& \text { Var }
\end{aligned}
$$

Frenulum faktörü

$$
\begin{aligned}
& \text { Yok } \\
& \text { Var }
\end{aligned}
$$

Yeterli yapışık dişeti

Yok
Var

Her bir katılımcıdaki dişeti çekilmesi sayısı
65

8

69

4

61

12

64

9

58

15

30

43

65

8

69

4

72

1

41,1

58,9

89

11

94,5

5,5

98,6

1,4

$49 \quad 67,1$

$24 \quad 32,9$

$3,01 \pm 2,05$

$2,0(1,0-10,0)$ 
Tablo 3.Dişeti çekilmesine etki eden faktörlerin ikili lojistik regresyon analizi ile incelenmesi

\begin{tabular}{|c|c|c|c|c|c|c|c|c|c|c|}
\hline & \multicolumn{5}{|c|}{ Tek değişkenli } & \multicolumn{5}{|c|}{ Çoklu lojistik regresyon analizi } \\
\hline & Beta & S. hata & OR (\%95 CI) & $p$ & DSO & Beta & S. hata & OR (\%95 CI) & $p$ & DSO \\
\hline Cinsiyet & 0,33 & 0,326 & $1,391(0,735-2,632)$ & 0,311 & 54,2 & & & & & \\
\hline Ĕ̆itim düzeyi & $-0,218$ & 0,197 & $0,804(0,546-1,183)$ & 0,268 & 57,5 & & & & & \\
\hline Yaş & 0,061 & 0,019 & $1,063(1,024-1,103)$ & 0,001 & 62,7 & 0,058 & 0,02 & $1,059(1,019-1,102)$ & 0,004 & \\
\hline Sistemik durum & 0,102 & 0,528 & $1,108(0,393-3,121)$ & 0,847 & 52,3 & & & & & \\
\hline Sigara & 0,56 & 0,386 & $1,75(0,821-3,728)$ & 0,147 & 56,2 & 0,811 & 0,427 & $2,251(0,975-5,194)$ & 0,057 & \\
\hline Diş hekimi ziyaret sıklığı & $-0,086$ & 0,192 & $0,917(0,629-1,337)$ & 0,653 & 52,3 & & & & & \\
\hline Diş fırçalama sıklığı & 0,222 & 0,166 & $1,248(0,901-1,729)$ & 0,182 & 58,2 & & & & & 69,3 \\
\hline Diş ipi kullanımı & $-0,805$ & 0,71 & $0,447(0,111-1,797)$ & 0,257 & 52,3 & & & & & \\
\hline Sağ -sol el kullanımı & $-0,442$ & 0,749 & $0,643(0,148-2,79)$ & 0,555 & 52,3 & & & & & \\
\hline Furçalama tekniği & 0,594 & 0,445 & $1,81(0,757-4,332)$ & 0,182 & 55,6 & 1,233 & 0,486 & $3,432(1,323-8,901)$ & 0,011 & \\
\hline Sondlamada kanama & 0,237 & 0,38 & $1,268(0,602-2,672)$ & 0,532 & 52,3 & & & & & \\
\hline Plak varlığı & $-0,109$ & 0,445 & $0,897(0,375-2,145)$ & 0,807 & 52,3 & & & & & \\
\hline Teşhis & 1,362 & 0,404 & $3,903(1,768-8,618)$ & 0,001 & 63,4 & 1,474 & 0,436 & $4,368(1,86-10,257)$ & 0,001 & \\
\hline
\end{tabular}

DSO: Doğru sınıflandırma oranı, (referans kategori)

Tablo 4.Dişeti çekilmesi ile ilişkili faktörlere göre dişeti çekilmesi sayısının karşılaştırılması

\begin{tabular}{|c|c|c|c|c|}
\hline \multirow{2}{*}{\multicolumn{5}{|c|}{ Ortalama \pm s. sapma Ortanca (min. - maks.)Test istatistiği }} \\
\hline & & & & \\
\hline Yok & $3,18 \pm 2,12$ & $2,00(1,00-10,00)$ & $\mathrm{t}=1,884$ & 0,064 \\
\hline Var & $1,75 \pm 0,46$ & $2,00(1,00-2,00)$ & & \\
\hline \multicolumn{5}{|c|}{ Aşınma } \\
\hline Yok & $2,84 \pm 2,01$ & $2,00(1,00-10,00)$ & $\mathrm{U}=457,5$ & 0,077 \\
\hline Var & $3,83 \pm 2,17$ & $3,50(1,00-8,00)$ & & \\
\hline \multicolumn{5}{|c|}{ Fırça izi } \\
\hline Yok & $3,00 \pm 2,11$ & $2,00(1,00-10,00)$ & $\mathrm{U}=306,0$ & 0,567 \\
\hline Var & $3,11 \pm 1,76$ & $3,00(1,00-7,00)$ & & \\
\hline \multicolumn{5}{|c|}{ Mobilite } \\
\hline Yok & $2,82 \pm 1,84$ & $2,00(1,00-8,00)$ & $\mathrm{t}=-1,545$ & 0,127 \\
\hline Var & $3,73 \pm 2,66$ & $4,00(1,00-10,00)$ & & \\
\hline \multicolumn{5}{|c|}{ Dentin hipersensitivitesi } \\
\hline Yok & $2,46 \pm 1,82$ & $2,00(1,00-8,00)$ & $\mathrm{U}=763,0$ & 0,030 \\
\hline Var & $3,38 \pm 2,14$ & $3,00(1,00-10,00)$ & & \\
\hline \multicolumn{5}{|c|}{ Oklüzal travma } \\
\hline Yok & $3,03 \pm 2,10$ & $2,00(1,00-10,00)$ & $\mathrm{t}=0,202$ & 0,840 \\
\hline Var & $2,88 \pm 1,73$ & $2,50(1,00-6,00)$ & & \\
\hline \multicolumn{5}{|c|}{ Frenulum faktörü } \\
\hline Yok & $3,24 \pm 2,35$ & $2,00(1,00-10,00)$ & $t=1,263$ & 0,211 \\
\hline Var & $2,60 \pm 1,32$ & $2,00(1,00-6,00)$ & & \\
\hline \multicolumn{5}{|c|}{ Yeterli yapışık dişeti } \\
\hline Yok & $3,36 \pm 2,23$ & $2,00(1,00-10,00)$ & $t=2,071$ & 0,042 \\
\hline Var & $2,30 \pm 1,43$ & $2,00(1,00-6,00)$ & & \\
\hline
\end{tabular}

*Diğer etiyolojik faktörlerin sayısı az olduğu için karşılaştırma yapılamamıştır, t: Bağımsız iki örnek t testi istatistiği, U: Mann-Whitney U test istatistiği 


\section{TARTIŞMA}

Bu çalışma, yetişkin bir popülasyonda dişeti çekilmesi insidansı ile bireysel karakteristikler, periodontal ve epidemiyolojik değişkenlerin olası ilişkilerini araştırmak amacıyla yapılmıştır. Dişeti çekilmelerinin epidemiyolojisini ve risk faktörlerini araştıran oldukça sınırlı sayıda araştırma mevcuttur. Çalışma sonuçları yaş, fırçalama tekniği, periodontal hastalık teşhisi, dentin hipersensitivitesi ve yetersiz yapışık dişeti varlığ değişkenlerinin dişeti çekilmesi vakalarında primer düzeyde ilişkili faktörler olduğunu göstermiştir.

Epidemiyolojik çalışmaların yapılması, bir tedaviye olan ihtiyacı veya önleyici müdahalelerin belirlenmesini sağlayabilmektedir. Epidemiyoloji, genellikle iki veya daha fazla bulgu arasındaki ortak ilişkileri ele almakta ve sebep-sonuç ile ilgili çeşitli varsayımları bu ortak ilişkilere dayandırmaktadır (Dodwad, 2001).

Çalışmaya katılan bireylerin yarısından fazlasında $(\% 52,1)$ dişeti çekilmesi tespit edilmiştir. Literatürde dişeti çekilmesi yaygınlığının mevcut çalışma bulguları ile uyumlu olduğu (Toker ve Ozdemir, 2009; Chrysanthakopoulos, 2013) veya çakıştığ1 (Mathur ve ark., 2009; Grover ve Aggarwal, 2012) çalışma bulgularına rastlanmaktadır. Dişeti çekilmesi prevelansının çalışmaya katılan örneklemler arasında farklılık göstermesi beklenen bir bulgudur. Mevcut araştırma bulgularına göre dişeti çekilmesi riski cinsiyete göre farklılık göstermemekte ve Chrysanthakopoulos'un çalışma bulgularını (2013) desteklemektedir. Ancak bu değişken için de literatürde çelişkili sonuçlara ulaşılmaktadır (Kozłowska ve ark., 2005; Sarfati ve ark., 2010).

$\mathrm{Bu}$ çalışmada dişeti çekilmesi riskinin yaşla birlikte arttığ1 gözlenmiştir. Literatür, ileri yaş grubunda dişeti çekilmesi sıklığının yüksek olduğunu doğrulamaktadır (Almeida ve ark., 2007). Dişeti çekilmesine neden olan faktörler kümülatif etkilerinin yanı sira konakta meydana gelen lokal ve sistemik değişikliklerle de ilişkilidir. Löe ve arkadaşlarına göre
(1992) periodontal dokuların yıkımı zamanla istikrarlı bir şekilde ilerler. Bu da ileri yaş grubunda daha fazla görülen dişeti çekilmesi vakalarını açıklayabilmektedir.

Araştırma bulguları, eğitim düzeyinin dişeti çekilmesi riskine etki etmediğini göstermektedir. Bu bulgularla uyumlu (Susin ve ark., 2004; Chrysanthakopoulos, 2013) veya çelişen sonuçlara rastlanmaktadır (Roman ve ark., 2009). Bu sonuç, eğitim düzeyi düşük bireylerde periodontal hastalığa bağlı, eğitim düzeyi yüksek bireylerde ise daha sık ve travmatik fırçalamaya bağlı atrofiler gözlenebilmesine bağlı elde edilmiş olabilir.

Bu çalışmada, sistemik hastalık varlığı ile dişeti çekilmesi riski arasında anlamlı bir ilişki tespit edilmemiştir. Literatürde bu konuda kesin kanit sunan bir makaleye rastlanmamıştır. Ancak sistemik hastalıklar ve periodontal hastalıklar arasındaki ilişki iyi bir şekilde belgelenmiş olduğundan (Bui ve ark., 2019), dolaylı olarak etki etmesi beklenebilir. Elde edilen bulgunun, kısıtlı sayıda bireyden oluşan araştırma örnekleminden kaynaklı olduğu düşünülmektedir.

Çalışma sonuçları, sigara kullanımı ile dişeti çekilmesi arasında anlamlı bir ilişki göstermemiştir. Önceki araştırmalar sigara kullanımının büyük oranda dişeti çekilmesi riskini artırdığına (Toker ve Ozdemir, 2009; Sarfati ve ark., 2010; Amarasena ve Ekanayake, 2010; Chrysanthakopoulos, 2013) işaret etse de çelişkili sonuçlara (Bokor-Bratić, 2002) da rastlanmaktadır. Çalışma örnekleminde bulunan katılımcıların büyük çoğunluğunun sigara kullanmıyor oluşu ve farklı çalışmalarda incelenen popülasyonların heterojenlik göstermesi bu bulguya neden olmuş olabilir.

Mevcut araştırma bulguları katılımcıların çoğunda plak ve sondlamada kanama varlığını göstermiştir. Ancak bu değişkenler, dişeti çekilme riskini anlamlı şekilde etkilememiştir. Bu durum incelenen popülasyonda ağız hijyeni iyi olan bireylerde de dişeti çekilmesi gözlendiğine işaret etmektedir. Literatür bilgisi plak, enflamasyon ve dişeti kanamasının 
dişeti çekilmesi riskini artırdığını sunmuştur (Murray, 1973; Toker ve Ozdemir, 2009; Chrysanthakopoulos, 2013; Seong ve ark., 2018). Bununla birlikte, Dodwad (2001), Bindu ve Cheru (1992) ve Chrysanthakopoulos (2013) tarafından yapılan çalışmalarda, dişeti çekilmesi etiyolojisinin, hatalı diş fırçalama, diş malpozisyonu, frenulum faktörü, anormal alışkanlıklar vb. çok faktörlü olduğu vurgulanmıştır. Çalışma bulgularımızda diş hekimi ziyaret sıklığı, fırçalama sıklığı ve diş ipi kullanımı gibi ağız hijyeni uygulamalarını gösteren değişkenler dişeti çekilmesi riski ile anlamlı ilişki göstermezken, fırçalama tekniği değişkeninde anlamlı bir ilişki görülmesi, yukarda geçen çalışmalarla desteklenmekte, plak ve sondlamada kanama olmayan bireylerde görülen dişeti çekilmesi vakalarını açılayabilmektedir. Nitekim diş fırçasının yatay yönde veya sert ve travmatik kullanımının, dişetinde küçük yırtılmalara, yaralanmalara veya dişlerde aşınmalara neden olabileceği ve sonuçta dişeti yarıkları veya atrofileri görülebileceği ifade edilmektedir (Joshipura ve ark., 1994; Kozłowska ve ark., 2005; Almeida ve ark., 2007). Dolayisıyla hastalara doğru teknikle diş fırçalama yöntemlerinin öğretilmesi oldukça önemlidir.

$\mathrm{Bu}$ araştırmada oklüzal travma ve mobilite dişeti çekilmesi ile ilişkilendirilemeyen başka değişkenler olarak karşımıza çıkmaktadır. 300 hastanın alt kesici dişlerinde oklüzal travma ve mobilite ile dişeti çekilmesi ilişkisini değerlendiren Kundapur ve ark. (2009) oklüzal travma ile anlamlı bir ilişki tespit etmemiş ancak mobilite değişkeninin sonuçlara anlamlı şekilde etki ettiğini belirtmişlerdir. Çalışma örnekleminde elde edilen bulgular, periodonsiyumun fizyolojik sinirların ötesinde olan kuvvetlere de kimi zaman dayanma kapasitesi bulunduğuna atfedilebilir. Bu kapasite aşıldığında dişeti hastalığının ilerlemesi ve periodontitis gelişmesi kaçınılmazdır. \%75,7 oranında katılımcıda ilerlemiş dişeti hastalığı (periodontitis) bulunmaması bu fikri desteklemektedir.

Tüm bunlarla birlikte, periodontitis teşhisi olanların dişeti çekilmesi riski gingivitis teşhisi olanlara göre
3,9 kat daha fazla bulunmuştur. Dişeti çekilmesinin periodontitis hastalarında daha fazla görülmesi, patolojik faktörler nedeniyle gelişen lokal enflamatuar ve immün cevaplara bağlanmıştır. Periodontitiste kemik yıkımı, bağ dokusu ataçmanının kaybı ve bağlantı epitelinin apikale migrasyonuile birlikte meydana gelmektedir (Beck ve Koch, 1994; Watson, 1984). Dolayısıyla, periodontitis vakalarında dişeti çekilmesinin daha yaygın görülmesi beklenen bir bulgudur.

Frenulum faktörü \%35,6 oranında katılımcıda mevcut olup hatrı sayılır bir değeri ifade etmektedir. Ancak dişeti çekilmesi riskine anlamlı bir etkisi tespit edilmemiştir. Frenulum faktörü dikkatli şekilde takip edilmesi gereken bir değişkendir. Çünkü lokalize dişeti çekilmesine sebep olabileceği, plak eliminasyonunu engelleyebileceği veya marjinal dişeti üzerine doğrudan bağlanarak dokunun gerilmesine neden olabileceği belirtilmektedir (Tugnait ve Clerehugh, 2001). Frenulum faktörünün dişeti çekilmesi riskine anlamlı etkisinin bulunmayışının, az sayıda katılımcıyı içeren kısıtlı bir popülasyonda çalışılmasına bağlı geliştiği düşünülmektedir.

$\mathrm{Bu}$ araştırma dentin hipersensitivitesi ile her bir bireydeki dişeti çekilmesi sayısı arasında anlamlı pozitif bir korelasyon olduğunu göstermiştir. Dişeti çekilmesi bulunan alanlarda dentin hipersensitivitesi bulunduğu (Francetti ve ark., 2018; Schlee ve ark., 2018), çekilme bölgesinin kapatılmasıyla bu duyarlılığın azaldığı önceki çalışmalarda doğrulanmış olup (Santamaria ve ark., 2018) çalışma bulgularımızı destekler niteliktedir. Dentin hipersentivitesine bağlı hissedilen ağrı, bireylerin yaşam kalitesini olumsuz yönde etkileyeceğinden, dişeti çekilmesi vakaları önlenmeli veya iyi bir şekilde yönetilmelidir. Bu da neden olan etiyolojik faktörlerin iyi bir şekilde anlaşılması gerekliliğini vurgulamaktadir.

Araştırma bulgularına göre, yetersiz yapışık dişeti genişliği olanlarda tespit edilen dişeti çekilmesi sayısı, yeterli yapışık dişeti genişliği olanlara göre 
anlamlı şekilde daha fazladır. Yapışık diş eti genişliğinin plak kontrolü sağlamada, ataşman kaybı ve diş eti çekilmesini önlemede oldukça önemli bir faktör olduğu literatürde kanıtlanmıştır (Malathi ve ark., 2013). Bu nedenle, yetersiz yapışık dişeti genişliği bulunan bireylerin, periodontal idame tedavisine uyum göstermesi, gerekli durumlarda yapışık dişeti miktarını artıracak tedaviler planlanması önem teşkil etmektedir.

$\mathrm{Bu}$ çalışmanın başlıca kısıtlılıkları, örneklem büyüklüğünün sinırlı olması ve tek merkezli bir çalışma olarak yürütülmesidir. Ayrıca, dişeti çekilmesine neden olma ihtimali bulunan dişeti fenotipi değişkeni incelenmemiş, hasta memnuniyeti değerlendirilmemiş ve estetik analiz yapılmamıştır. Dişeti çekilmesine neden olan etiyolojik faktörler ve sonuçları ile ilişkili durumları araştıran daha kapsamlı çalışmalar planlanması önerilmektedir.

$\mathrm{Bu}$ çalışmanın sınırları dahilinde, dişeti çekilmesi insidansının incelenen popülasyonda yaygın olduğu gözlenmiştir. Dişeti çekilmesi riski, yaş, hatalı fırçalama teknikleri, yetersiz yapışı dişeti genişliği ve ilerlemiş periodontal hastalık varlığında artmaktadır. Dentin hipersensitivitesi ise dişeti çekilmesi ile ilişkili faktörler arasında öne çıkmaktadır.

\section{Teşekkürler}

Yazarlar araştırmada verileri kullanılarak bilime katkı sağlayan hastalara teşekkür etmektedir.

\section{Çıkar Çatışması}

Yazarlar çıkar çatışması olmadığını beyan eder.

\section{KAYNAKLAR}

Addy M. Tooth brushing, tooth wear and dentine hypersensitivity - are they associated? Int Dent J 2005; 55: 261-7.

Ainamo J, Bay I. Problems and proposals for recording gingivitis and plaque. Int Dent J 1975; 25(4): 229-35.

Almeida AL, Madeira LC, Freitas KC, Greghi SL, Pegoraro, LF. Cross-sectional evaluation of the presence of gingival recession in individuals with cleftlip and palate. J Periodontol 2007;78(1):29-36.

Amarasena G, Ekanayake L. Periodontal status and associated factors in 15-year-old Sri Lankans. J Investig Clin Dent 2010; 1(2): 74-8.

Banihashemrad S, Fatemi K, Najafi M. Effect of smoking on gingival recession. Dent Res J 2008;5:1-4.

Beck J, Koch G. Characteristics of the elderly with periodontal attachment loss as gingival recession or probing depth. J Periodontal Res 1994;29: 290-8.

Bekes K, Hirsch C. What is known about the influence of dentine hypersensitivity on oral health-related quality of life? Clin Oral Investig 2013; 17: 45-51.

Bernimoulin J, Curilovié Z. Gingival recession and tooth mobility. J Clin Periodontol 1977;4(2):107-14.

Bindu R, Cheru T. Prevalence and etiology of gingival recession-An epidemiological study. ISP Bull 1992; 16: 4-8.

Bokor-Bratić M. Effects of smoking on the periodontium. Med Pregl 2002; 55: 229-32.

Bui FQ, Almeida-da-Silva CLC, Huynh B, Trinh A, Liu J, Woodward J, et al. Association between periodontal pathogens and systemic disease. Biomed J 2019; 42(1): 27-35.

Caton JG, Armitage G, Berglundh T, Chapple I, Jepsen S, Kornman KS, et al. A new classification scheme for periodontal and peri-implant diseases and conditions -Introduction and key changes from the 1999 classification. J Clin Periodontol 2018; 45: 1-8.

Chrysanthakopoulos NA. Prevalence and associated factors of gingival recession in Greek adults. J Investig Clin Dent 2013; 4(3),:178-85.

Chrysanthakopoulos NA. Gingival recession: prevalence and risk indicators among young greek adults. J Clin Exp Dent 2014; 6(3): 243-9. 
Dodwad V. Etiology and severity of gingival recession among young individuals in Belgaum district in India. Ann Dent Univ Malaya 2001;8:1-6.

Francetti L, Weinstein R, Taschieri S, Corbella S. Coronally advanced flap with or without subepithelial connective tissue graft for the treatment of single recession: 5-Year outcomes from a comparative study. Int J Periodontics Restorative Dent 2018; 38(6): 819-25.

Grover H, Aggarwal N. Observational study on the association between gingival recession and other clinical variables in an adult population in India. Indian J Dent Sci 2012; 4: 1-7.

Hanamura H, Houston F, Rylander H, Carlsson GE, Haraldson T, Nyman S. Periodontal status and bruxism. A comparative study of patients with periodontal disease and occlusal parafunctions. J Periodontol 1987; 58(3): 173-6.

Joshipura KJ, Kent RL, De Paola PF. Gingival recession: intra-oral distribution and associated factors. J Periodontol 1994; 65(9): 864-71.

Kassab MM, Cohen RE. The etiology and prevalence of gingival recession. J Am Dent Assoc 2003; 134(2): 220-5.

Kisch J, Badersten A, Egelberg J. Longitudinal observation of "unattached," mobile gingival areas. J ClinPeriodontol 1986; 13(2): 131-4.

Kozłowska M, Wawrzyn-Sobczak K, Karczewski JK, Stokowska W. The oral cavity hygiene as the basic element of the gingival recession prophylaxis. Rocz Akad Med Bialymst 2005; 50: 234-7.

Kundapur PP, Bhat KM, Bhat GS. Association of trauma from occlusion with localized gingival recession in mandibular anterior teeth. Dent Res J 2009; 6(2): 71-4.

Löe H, Anerud A, Boysen $\mathrm{H}$. The natural history of periodontal disease in man: prevalence, severity, andextent of gingival recession. J Periodontol 1992; 63(6): 489-95.
Mathur A, Jain M, Jain K, Samar M, Goutham B, Swamy PD, et al. Gingival recession in schoolkidsaged 10-15 years in Udaipur, India. J Indian Soc Periodontol 2009; 13(1): 16-20.

Malathi K, Arjun S, Blaisie R. Attached gingiva: a review. Int J Sci Res Rev. 2013; 3(2): 188-98.

Mirko P, Miroslav S, Lubor M. Significance of the labial frenum attachment in periodontal disease in man. Part I. Classification and epidemiology of the labial frenum attachment. J Periodontol 1974; 45(12): 891-4.

Murray JJ. Gingival recession in tooth types in high fluoride and low fluoride areas. J Periodontal Res 1973; 8(4): 243-51.

Roman A, Louise F, M'barek R, Brun-el-Trotebas S. Gingival recessions: epidemiologic, etiologic and therapeutic aspects. Intern J Dent Sci 2009;7:1.

Sangnes G, Gjermo P. Prevalence of oral soft and hard tissue lesions related to mechanical tooth cleansing procedures. Community Dent Oral Epidemiol 1976; 4(2): 77-83.

Santamaria MP, Silveira CA, Mathias IF, Neves F, DosSantos LM, Jardini M, et al. Treatment of single maxillary gingival recession associated with non-carious cervical lesion: randomized clinical trial comparing connective tissue graft alone to graft plus partialrestoration. J ClinPeriodontol. 2018; 45(8): 968-76.

Sarfati A, Bourgeois D, Katsahian S, Mora F, Bouchard P. Risk assessment for buccal gingival recession defects in an adult population. J Periodontol 2010; 81(10): 1419-25.

Schlee M, Rathe F, Bommer C, Bröseler F, Kind L. Self-assembling peptide matrix for treatment of dentin hypersensitivity: A randomized controlled clinical trial. J Periodontol 2018; 89(6): 653-60. 
Seong J, Bartlett D, Newcombe RG, Claydon NCA, Hellin N, West NX. Prevalence of gingival recession and study of associated related factors in young UK adults. J Dent 2018;76:58-67.

Shkreta M, Atanasovska-Stojanovska A, Dollaku B, Belazelkoska Z. Exploring the gingival recession surgical treatment modalities: a literature review. Open Access Maced J Med Sci 2018; 6(4): 698-708.

Silness J, Löe H. Periodontal disease in pregnancy. II. Correlation between oral hygiene and periodontal condition. Acta Odontol Scand 1964; 22: 121-35.

Susin C, Haas AN, Oppermann RV, Haugejorden O, Albandar JM. Gingival recession: epidemiology and risk indicators in a representative urban Brazilian population. J Periodontol 2004; 75(10): 1377-86.
Toker H, Ozdemir H. Gingival recession: epidemiology and risk indicators in a university dental hospital in Turkey. Int J Dent Hyg 2009; 7(2): 115-20.

Tugnait A, Clerehugh V. Gingival recession-its significance and management. J Dent 2001; 29(6): 381-94.

Vehkalahti M. Occurrence of gingival recession in adults. J Periodontol.1989; 60(11): 599-603.

Watson PJ. Gingival recession. J Dent. 1984; 12(1): 29-35.

Zucchelli G, Testori T, De Sanctis M. Clinical and anatomical factors limiting treatment outcomes of gingival recession: a new method to predetermine the line of root coverage. J Periodontol 2006; 77(4): 714-21. 